"The impact of monetary policy shocks on the equity risk premium before and after the Quantitative Easing in the United Kingdom"

\begin{tabular}{|c|c|c|}
\hline AUTHORS & \multicolumn{2}{|l|}{$\begin{array}{l}\text { Sunil Poshakwale } \\
\text { Pankaj Chandorkar }\end{array}$} \\
\hline ARTICLE INFO & \multicolumn{2}{|c|}{$\begin{array}{l}\text { Sunil Poshakwale and Pankaj Chandorkar (2016). The impact of monetary policy } \\
\text { shocks on the equity risk premium before and after the Quantitative Easing in the } \\
\text { United Kingdom. Investment Management and Financial Innovations, 13(4-1), } \\
\text { 146-159. doi:10.21511/imfi.13(4-1).2016.01 }\end{array}$} \\
\hline DOI & \multicolumn{2}{|c|}{ http://dx.doi.org/10.21511/imfi.13(4-1).2016.01 } \\
\hline RELEASED ON & \multicolumn{2}{|l|}{ Thursday, 29 December 2016} \\
\hline JOURNAL & \multicolumn{2}{|c|}{ "Investment Management and Financial Innovations" } \\
\hline FOUNDER & \multicolumn{2}{|c|}{ LLC "Consulting Publishing Company "Business Perspectives" } \\
\hline$\sigma^{\circ}$ & 15 & $\begin{array}{l}\text { ニニミ } \\
\text { ニニこ }\end{array}$ \\
\hline NUMBER OF REFERENCES & NUMBER OF FIGURES & NUMBER OF TABLES \\
\hline 0 & 0 & 0 \\
\hline
\end{tabular}

(c) The author(s) 2022. This publication is an open access article. 
Sunil Poshakwale (United Kingdom), Pankaj Chandorkar (United Kingdom)

\title{
The impact of monetary policy shocks on the equity risk premium before and after the quantitative easing in the United Kingdom
}

\begin{abstract}
The authors investigate the impact of structural monetary policy shocks on ex-post equity risk premium (ERP) of aggregate and sectoral FTSE indices and 25 Fama-French style value-weighted portfolios. They find that monetary policy shocks negatively affect the ERP but at the sectoral level, the magnitude of the response is heterogeneous. Further, monetary policy shocks have a significant negative (positive) impact on the ERP before (after) the implementation of quantitative easing (QE). The empirical evidence provided in the paper sheds light on the equity market's asymmetric response to the BoE's policy before and after the monetary stimulus.
\end{abstract}

Keywords: monetary policy, equity risk premium, quantitative easing, monetary policy shocks, structural vector autoregression, Bank of England, Taylor monetary policy rule, unconventional monetary policy, output gap, inflation gap, Okun's law.

JEL Classification: E5, E30, G0, G1.

\section{Introduction}

The UK's monetary policy has twin objectives of price and financial stability. Consequently, the Monetary Policy Committee (MPC) of Bank of England $(\mathrm{BoE})$ has to maintain $2 \%$ target inflation as required by the Treasury, whilst the Financial Policy Committee (FPC) monitors the systemic risks to the financial markets. There are various channels through which the impact of monetary policy could be transmitted to the economy and these have been discussed in the extant literature (see for example, Bernanke and Blinder, 1992, Bernanke and Kuttner, 2005). Mishkin (1996) explains how stock markets act as one of the important channels of monetary policy transmission. Changes in the monetary policy, measured either using changes in money supply or changes in short term interest rates, should induce revaluations in the stock market. Contractionary or expansionary monetary policy should affect future expected returns through the changes in discount rates at which the future expected dividends are discounted. This paper investigates the impact of monetary policy shocks on the equity risk premium (ERP) in the UK before and after the quantitative easing $(\mathrm{QE})$ which was introduced in the wake of 2007-2008 financial crisis.

There is extensive research that examines the response of stock market returns to domestic monetary policy shocks, particularly in the US. (see, for example, Bernanke and Blinder (1992), Thorbecke (1997), Gilchrist and Leahy (2002), Rigobon and Sack (2003, 2004), Bernanke and Kuttner (2005), Ioannidis and Kontonikas (2008) and Castelnuovo and Nisticò (2010)]. However, research on the UK

(C) Sunil Poshakwale, Pankaj Chandorkar, 2016.

Sunil Poshakwale, BCom, DCMA, MBA, PhD (Manchester), Professor of International Finance, Director of Centre for research in Finance, School of Management Cranfield University, UK.

Pankaj Chandorkar, Doctoral Researcher, Centre for research in Finance, Cranfield School of Management, UK. market is relatively sparse and dated. Bredin, Hyde, Nitzsche and O'reilly (2007) examine the behavior of UK stock returns both at aggregate and industry level in response to UK domestic monetary policy shocks. They decompose the changes in the policy rate as expected and unexpected changes and report that the impact of monetary policy shocks on the UK stock market is heterogeneous, i.e., the sensitivity of aggregate stock market to the shocks in the domestic policy changes is different as compared to the impact at the industry level. While the impact of monetary policy shocks on the stock market before the financial crisis of 2007-2008 has been studied under the conventional monetary policy framework, the impact on the ERP before and after unconventional monetary policy is still emerging.

Under the conventional monetary policy, BoE uses inflation targeting which is operationalized using a single monetary policy instrument, i.e., the interest rate. However, in the aftermath of the financial crisis, BoE was confronted with multiple challenges. On the hand, it was required to maintain the target inflation and on the other hand, it had to provide liquidity to the interbank market. As a consequence, the MPC was authorised by the Chancellor of the Exchequer to set up large scale Asset Purchase Facility (APF). Under this facility, the BoE purchased high quality assets such as Treasury Bills and Bonds from the private sector financed by creating central bank reserves. In addition to buying government securities, the BoE also purchased private sector assets such as corporate bonds to provide much needed liquidity. ${ }^{1}$ Thus, the QE became the primary monetary policy tool for the BoE.

\footnotetext{
${ }^{1}$ This form of unconventional monetary policy was first adopted by the Japanese Central Bank in the 1990s and is known as quantitative easing $(\mathrm{QE})$, because the monetary policy is operationalized by purchasing large quantities of high quality assets which leads to the expansion of the balance sheet of the bank rather than through the traditional interest rate lever.
} 
The channels through which the QE programme can affect asset prices are discussed by Krishnamurthy and Vissing-Jorgensen, (2011). Out of the seven possible channels that they postulate, the signalling channel seems to be more promising. Under this channel, the inclination of a central bank to keep the interest rate lower than that implied by the Taylor (1993) rule leads to lower yields on long-term bonds and higher prices of risky assets. In the case of the UK, Miles, $(2011,2012)$ discusses two main channels of transmission of $\mathrm{QE}$ effects to the broader asset markets. The first is the portfolio substitution channel which is also known as portfolio re-balancing channel ${ }^{1}$. Under this channel, the BoE buys gilts from the non-bank private sector investors, such as pension funds and insurance companies by financing the purchase using central bank reserves. However, these deposits are likely to be imperfect substitutes of the assets that are sold by the private sector to the BoE. Since pension funds and insurance companies have long-dated liabilites, they match the libaility duration by purchasing long term government bonds. This leads to declining yields on long dated bond, thus, reducing the termpremia. Additionally, declining yields on long term bonds encourage the private sector to raise new debt for financing new investments and/or dividend payments to equity holders ${ }^{2}$.

The genesis of the portfolio rebalancing channel could also be found in the monetary portfolio model (the name was coined by Rozeff (1974), developed by Friedman (1961)). In this model, investors are expected to attain equilibrium between different assets in their portfolio which includes money. Any exogenous monetary shock such as arising from changes to money supply would encourage investors to exchange cash for equities and/or bonds. This will affect real money balances and returns on equities and bonds.

The second channel through which the effects of QE could be transmitted to broader asset markets and ultimately to the wider economy is through the bank lending. Since the BoE finances purchase of gilts from bank and non-bank instititions through reserves, there is an overall rise in deposits in the banking system. This leads to an overall increase in lending to the small and medium scale industries and household sector which, in turn, encourages investors to invest in riskier assets such as equities.

\footnotetext{
${ }^{1}$ The theoretical underpinning of portfolio re-balancing channel, i.e., the idea of imperfect asset substitution has a long tradition in macroeconomics (see, Tobin, 1969).

${ }^{2}$ See, The Distributional Effects of Asset Purchases. Bank of England $12^{\text {th }}$ July 2012. Available through:

http://www.bankofengland.co.uk/publications/Documents/news/2012/ nr073.pdf.
}

Figure 1(see Appendix) provides anecdotal evidence of the impact of $\mathrm{QE}$ on the UK stock prices. In particular, the figure shows the impact of $\mathrm{QE}$ announcements on the closing prices of FTSE 100 index. The effects are clearly visible following the BoE's decisions in March 2009 to purchase $£ 75$ billion of assets, in October 2011 to increase the QE programme to $£ 275$ billion, and in July 2012 to further increase the asset purchases to $£ 375$ billion.

Extant research too, shows the efficacy of unconventional monetary policy and its impact on various asset prices. For example, Gagnon et al. (2010, 2011) show that QE not only reduces the yields of bonds bought under the scheme, but also yields of bonds which were not purchased under the Large Scale Asset Purchase programme. The findings reported by Gagnon et al., $(2010,2011)$ are further supplemented by Joyce, Lasaosa, Stevens and Tong (2011) who investigate the impact of QE programme on the UK asset prices. They find that following the $\mathrm{QE}$, the yields of the investment and speculative grade corporate bonds decline by 70 basis points (bps) and 150 bps respectively. Additionally, they also investigate the impact of QE on equity prices around the announcement of the QE programme. They conclude that equity prices show an increase since the start of QE in March 2009. Further, Meier (2009) provides evidence of decline in yields following BoE's asset purchase programme. Glick and Leduc (2012) suggest that the impact on yields is not restricted to the US and UK as their research shows that long term interest rates decline globally following the announcements of the QE programme by the Federal Reserve (FED) and the BoE.

Although there is a consensus that QE leads to declining bond yields, it is not empirically shown how the QE affects the ERP. In this paper, we investigate and compare the response of ERP to the monetary policy shocks before and after the introduction of QE. The approaches to identify exogenous monetary policy shocks can be broadly classified in two categorized; event study and Structural Vector Autoregression (SVAR). Previous research which use the event study approach have significant limitations. In an event study approach, the strategy of analysing impact of monetary policy shocks on asset market returns around a narrow window of time, does not explicitly account for the feedback rule. It is important that the model should include feedback based on changes to other macroeconomic variables such inflation, changes in unemployment, etc. to capture the impact of monetary policy shocks. The SVAR approach explicitly accounts for a feedback rule. One of the distinguishing features of monetary policy shocks identified using SAVRs is that, apart from being exogenous, they represent the deviations 
from expected policy response. These deviations may arise from discretionary policy due to abnormal events, changes in the composition of MPC, changes in either the weights associated with target variables, and/or changing the target variables itself. Further, as the systematic component of monetary policy can be captured by a standard monetary policy reaction rule, the deviations from such a rule can also be interpreted as a non-systematic component of monetary policy (see Christiano, Eichenbaum and Evans, 1996;1999 and Kilian 2012).

We, therefore, use SVAR approach which overcomes the limitation of the event study approach. Further, innovations in the short-term interest rates derived from SVAR are a more reliable proxy of monetary policy shocks (Bernanke and Blinder, 1992 and Sims, 1992. Subsequently Gali, 1992, Pagan, 1995, Christiano, Eichenbaum and Evans, 1996; 1999 Kim, 2001 and others have relied on identifying monetary policy shocks as innovations in the short term interest rates rather than money supply. In the paper, we use shocks in interest rates as a proxy of monetary policy shocks. There is evidence which suggests surprises in interest instruments should be a preferred way to measure monetary policy shocks. For example, Eggertsson and Woodford, 2003 suggest that although at zero-lower bound a central bank can stimulate the economy by purchasing assets on open market and thereby (in theory) expanding the monetary base, yet such a policy cannot be entirely considered as a main policy instrument. They stress that optimal monetary policy can be operationalized by using short-term interest as a policy instrument. We, therefore, rely on this normative framework and extract the structural monetary policy shocks in the interest rate instrument of monetary policy using a SVAR approach ${ }^{1}$.

We investigate the impact of monetary policy shocks on the aggregate and disaggregate data. We calculate monthly ERP for the FTSE 100, FTSE 250, and ten sectoral FTSE ALL indices which include Basic Materials, Consumer Services, Consumer Goods, Financials, Healthcare, Industrials, Oil and Gas, Telecom, Utilities and Technology. Use of disaggregated data will enable us to confirm whether the impact of monetary policy shocks is heterogeneous amongst the various industries. There are several reasons the impact may differ across industries. First, the demand for product and services may have different interest rate-sensitivity. Second, under the rational assumption that exchange

\footnotetext{
${ }^{1}$ SVAR approach is the workhorse of macroeconomics to analyse the rich dynamic effects of structural shocks in the monetary policy [see,Bernanke (1986), Thorbecke (1997),Bjørnland and Leitemo (2009),Lastrapes (1998); and Neri (2004)]
}

rates may respond to monetary policy shocks, the sensitivity of demand for the tradable goods and services may change due to fluctuations in the exchange rate caused by the monetary policy shocks. Third, capital-intensive industries, cyclical industries and financial services industries may react differently due to different interest-rate sensitivities (Ehrmann and Fratzscher, 2004).

We also investigate the impact of monetary policy shocks on the 25 Fama-French style value weighted portfolios based on the firm characteristics such as size and book-to-market ratios. Since Bernanke and Kuttner (2005) show that the risk premia varies across the cross-section of the market (i.e. size and the value premia are different), we expect that monetary policy shocks may have heterogeneous impact on the portfolios formed on the basis of value and size. By investigating the impact of monetary policy shocks on the ERP of portfolios constructed on the basis of size and value characteristics, we will be able to validate other channels of monetary policy transmission vis-à-vis the balance sheet channel and the bank lending channel (Mishkin, 1996). The balance sheet channel implies that a positive monetary policy shock would severely dampen the revenues of firms, particularly small firms, and increase their cost of financing. On the other hand, the bank lending channel has more direct impact on small firms. Small firms depend more on bank loans than big firms. In the event of positive monetary policy shocks, credit becomes more expensive for small firms. In either case, positive monetary policy shock could lead to an increase in the ERP depending on the firm size.

Our contribution to the existing literature is threefold. First, as far as we are aware, there is no study that has shown the impact of monetary policy shocks before and after the implementation of QE. Second, as suggested by Doh, Cao and Molling (2015), the impact of monetary policy shocks on ERP may reveal useful insights of the effects of macroeconomic events which are not captured by conventional macroeconomic factors such as inflation and output gap. Finally, since ERP is a key component for evaluating the cost of capital and asset allocation decisions, it is vital to understand how it responds to monetary policy innovations.

Our results show that a positive monetary policy shock, i.e. when the actual interest rates are more than the expected interest rates has a negative impact on the ERP of most of the FTSE Indices. However, the magnitudes of the sensitivities of the ERP are different suggesting that monetary policy shocks have a heterogeneous impact on different industries. Our findings are similar for the 25 Fama-French style value-weighted portfolios constructed on size 
and book-to-market ratios. Our results are consistent with those reported by Bernanke and Kuttner (2005) for the US market. Additionally, we find that excess returns of the value stocks are statistically more sensitive to the monetary policy shocks than the growth stocks.

Most notably, we report evidence of asymmetric response to the monetary policy shocks before and after the QE. Before the introduction of QE, the ERP react negatively to the monetary policy shocks. However, after QE, the monetary policy shocks have a positive impact on the ERP. We find similar results for the 25 Fama-French style portfolios. These results suggest that $\mathrm{QE}$ has had a positive effect on equity returns.

The rest of the paper is organized as follows, section 1 explains methodology, Section 2 describes the data, Section 3 reports empirical results, and Section 4 concludes.

\section{Methodology}

1.1. Identification of monetary policy shocks. We identify structural monetary policy shocks by including a set of macroeconomic variables and a monetary policy instrument using the SVAR framework. The SVAR approach allows modelling of the non-recursive structures with parsimonious set of variables.

We model the economy using the following the SAVR.

$\boldsymbol{A} Y_{t}=\boldsymbol{A}^{*}(L) Y_{t-1}+\boldsymbol{B} u_{t}$

where $\boldsymbol{Y}$ is a $n$ dimensional vector of macroeconomic variables including a monetary policy variable, $\boldsymbol{A}^{*}(L)$ is the $\mathrm{p}^{\text {th }}$ order polynomial matrix in the lag operator $L, \boldsymbol{A}$ is the $n \times n$ matrix of contemporaneous coefficients, $\boldsymbol{B}$ is a $n \times n$ matrix relating the structural innovations $u_{t}$ to the reduced form innovations and $u_{t} \sim N(0, \Sigma)$ is a $n \times 1$ vector of structural shocks which assume ortho-normal co-variance matrix as an identity matrix, i.e., $E\left[u, u^{\prime}\right]=I$.

In order to estimate (1), we, first, estimate the reduced form of (1) which is

$\boldsymbol{Y}_{t}=\boldsymbol{C}(L) \boldsymbol{Y}_{t-1}+\varepsilon_{t}$,

where $\varepsilon_{t}^{i}$ is the reduced form residuals such that

$$
\left.E\left(\varepsilon_{t}, \varepsilon_{s}\right)=\begin{array}{l}
E(\varepsilon)=0 \\
\\
\\
0, \\
t \neq s
\end{array}\right]^{\text {when }}
$$

$\Omega=\mathrm{E}\left[\varepsilon^{t}, \varepsilon^{S}\right]$ is the residual covariance matrix. Condition (3) implies that there is no serial correlation among the reduced-form disturbances, however, contemporaneous correlation is allowed. Following Amisano and Giannini (1997) and Lutkephol (2005), we have:

$$
A \cdot \varepsilon_{\mathrm{t}}=B \mathrm{u}_{\mathrm{t}}
$$

The assumption of ortho-normal covariance matrix of the structural shocks leads to following condition

$$
\boldsymbol{A} \Omega A^{\prime}=\boldsymbol{B} \boldsymbol{B}^{\prime}
$$

Thus, we have $\frac{1}{2} n(n+1)$ equations and $n^{2}$ elements in $\boldsymbol{A}$ and $\boldsymbol{B}$ each, which leads to additional $2 n^{2}-\frac{1}{2} n(n+1)$ restrictions to just identify the elements in $A$ and $B$. We impose short-run restrictions on $\boldsymbol{A}$ and $\boldsymbol{B}$ with $\boldsymbol{A}$ to be a lower triangular matrix with ones along the diagonal and $\boldsymbol{B}$ to be a diagonal matrix in order to extract the structural orthogonal monetary policy shocks. The lower triangularity implies standard Cholesky decompositions of the variance-covariance matrix which has economic implications. The short-run restrictions implied by (4) were also used by Gali (1992) and Pagan (1995) to study and test the traditional IS-LM model to the post-war US data.

We consider five macroeconomic variables in the SVAR. Out of the five macroeconomic variables, four are the information variables and the fifth is the monetary policy variable. Thus, we have

$$
\boldsymbol{Y}_{t}=\left[y_{t}, \pi_{t}, u m p_{t}, x_{t}, m p_{t}\right]
$$

where the information variable $y_{t}$ is the output gap which is measured by the deviation of index of the industrial production from its trend, $\pi_{t}$ is the inflation gap, measured using the deviation of the actual inflation from the target inflation, $u m p_{t}$ is the unemployment rate, $x_{t}$ is the trade-weighted effective exchange rate index and $m p_{t}$ is the monetary policy instrument. We use the BOE's base rate as the policy instrument to estimate the structural monetary policy shocks.

By ordering the variables in this fashion, we assume that all the four information variables contemporaneously affect the monetary policy variable; however the monetary policy affects these variables only with lag. It takes some time for output gap, inflation gap, unemployment and changes in exchange rates to respond to monetary policy actions. These assumptions are consistent with Christiano, Eichenbaum and Evans (1996). The structural monetary policy shocks are then the corresponding distur- 
bances in (1). The last equation in the VAR resembles monetary policy reaction function or the feedback rule which can be considered as a modified Taylor (1993) rule. It also takes into account the Okun's(1962) law. We include trade-weighted exchange rate as an information variable, since the BOE follows open-economy monetary policy (Ball, 1999a, 1999b; Svensson, 2000).

Equation (4) can be expressed in the matrix form as;

$$
\begin{aligned}
& {\left[\begin{array}{ccccc}
1 & 0 & 0 & 0 & 0 \\
a_{21} & 1 & 0 & 0 & 0 \\
a_{31} & a_{32} & 1 & 0 & 0 \\
a_{41} & a_{42} & a_{43} & 1 & 0 \\
a_{51} & a_{52} & a_{53} & a_{54} & 1
\end{array}\right] \cdot\left[\begin{array}{c}
\varepsilon_{t}^{y} \\
\varepsilon_{t}^{\pi} \\
\varepsilon_{t}^{m p} \\
\varepsilon_{t}^{x} \\
\varepsilon_{t}^{m p}
\end{array}\right]=} \\
& =\left[\begin{array}{ccccc}
b_{11} & 0 & 0 & 0 & 0 \\
0 & b_{22} & 0 & 0 & 0 \\
0 & 0 & b_{33} & 0 & 0 \\
0 & 0 & 0 & b_{44} & 0 \\
0 & 0 & 0 & 0 & b_{55}
\end{array}\right] \cdot\left[\begin{array}{c}
u_{t}^{y} \\
u_{t}^{c p i} \\
u m p \\
u t \\
u_{t}^{x} \\
u_{t}^{m p}
\end{array}\right]
\end{aligned}
$$

Thus, from (7), the structural monetary policy shocks are estimated ${ }^{1}$ as:

$$
\begin{gathered}
b_{55} \cdot u_{t}^{m p}=a_{51} \cdot \varepsilon_{t}^{y}+a_{52} \cdot \varepsilon_{t}^{\pi}+a_{53} \cdot \varepsilon_{t}^{u m p} \\
+a_{54} \cdot \varepsilon_{t}^{x}+\varepsilon_{t}^{m p}
\end{gathered}
$$

\subsection{The impact of monetary policy shocks on the}

ERP. In the previous sub-section we described the methodology to uncover the structural monetary policy shocks. We now examine the effect of these structural shocks on the UK ERP by estimating the following regression model;

$E_{i, t}=\alpha_{i}+\beta_{i} u_{t}^{m p}+e_{i, t}$

Where, $E_{i, t}$ is the UK ERP (measured using the expot excess returns on portfolio $i$ over the 1-month treasury bills rate), $\alpha_{i}$ is the constant which can also be interpreted as pricing error, $\beta_{i}$ is the sensitivity of the ERP of the $i^{\text {th }}$ portfolio to the monetary policy shocks $u_{t}^{m p}$ and $e_{i, t}$ is a white noise process. We investigate the impact of monetary policy shocks for three types of portfolios. In the first portfolio, we calculate excess returnsfor two popular and mostly tracked indices in the UK, the FTSE 100 index and the FTSE 250 index. These two indices serve as a benchmark for most of the fund managers. In the second portfolio, we compute excess returns for ten most widely used UK sectoral indices. In the third

${ }^{1}$ See Christiano, Eichenbaum and Evans (1996) and Kim (2001). portfolio, we calculate the excess returns on valueweighted 25 Fama-French-style portfolios sorted on size and book-to-market. The goal here is to examine whether the impact is consistent and significant. Model (9) is estimated using maximum likelihood technique employing Marquardt optimisation algorithm assuming that errors follow a normal distribution. This is because our initial estimation of model (9) using OLS showed the presence of ARCH effects in the residuals.

\section{Data description}

We obtain monthly data for the period of January 1988 to October 2014 from DataStream. To measure the output gap, we use the seasonally adjusted index of industrial production. The output gap is estimated as the deviation of the index of industrial production from its potential trend. ${ }^{2}$ The inflation gap is estimated using the deviation of actual inflation from the target inflation. The UK adopted inflation target regime in October 1992 following the departure of the UK from the Exchange Rate Mechanism. The target annual inflation was in the range of $1 \%-4 \%$, as measured by the inflation in the Retail Price Index excluding mortgage interest payments (RPIX). In May 1997, the Chancellor of the Exchequer set the initial target of 2.5\%. In December 2003, the annual inflation target was once again changed to $2 \%$ measured in inflation of Harmonized Consumer Price Index (HCPI). In our study, we use $2.5 \%$ annual inflation target in RPIX until November 2003 and a target of $2 \%$ annual in HCPI from December 2004. Unemployment rate is measured as unemployed workforce as a percentage of economically active workforce claiming unemployment benefits i.e., Job Seekers Allowance and National Insurance Credits. The trade-weighted exchange rate of the British Sterling Pound is measured using Effective Exchange Rate Index. We calculate the ERP as the difference between monthly returns ${ }^{3}$ of FTSE 100 index, FTSE 250 index and the ten major sectors and the yield on 1-month UK treasury bills. The returns on the 25 Fama-French style portfolios are taken from Gregory, Tharyan and Christidis, (2013).

Table 1 (see Appendix Table 1) provides the descriptive statistics. Panel A shows that over the sample period, the average annualised growth rate in the industrial production is $0.08 \%$. The average inflation is $3.13 \%$. On average the trade weighted effective exchange rate has declined with an average annual rate of $-0.4 \%$. The average base rate has been $5.5 \%$ for the sample period.

\footnotetext{
2 The trend of the index of the industrial production is estimated via the Hodrick Prescott filter using the "punishing" parameter $(\lambda=14400)$, ${ }^{3}$ The returns are calculated using total returns index which include dividends.
} 
Panel B provides descriptive statistics of annualised ERP of FTSE 100, FTSE 250 and the ten sector indices. It can be seen from Panel B that on an average, Utilities is the best performing sector with average annual ERP of $8.96 \%$ while the Technology sector offers the lowest ERP of $1.16 \%$. Overall, on average ERPs are positive for all portfolios. Panel C provides the descriptive statistics of the annualised ERPs of the 25 value-weighted Fama-French style portfolios based on size and book-to-market characteristics. For simplicity we maintain the same naming convention of the portfolios as in Gregory et. al. (2013). The average annualised ERP of small size portfolios is $6.82 \%$ while the average ERP of big size portfolios is $5.16 \%$. On the growth and value dimensions, the average annualised ERPs of growth and value portfolios are $4.8 \%$ and $7.8 \%$ respectively.

\section{Results}

3.1. The impact of structural monetary policy shocks on ERP. First, we examine the impact of the contemporaneous structural monetary policy shocks. This gives us an overall understanding of how ERP of aggregate market, ten different sectors and 25 Fama-French portfolios respond to the structural monetary policy shocks over the entire sample period. We estimate the regression model (9) and report the results in Table 2 (see Appendix).

We find that the monetary policy shocks impacts the ERP negatively. Although there is heterogeneity in the magnitude and the significance of the impact of monetary policy shocks on different FTSE indices, yet with the only exception of the utilities sector, ERPs of all other sectors react negatively. Whilst, Basic Materials, Financials, Consumer services, Industrials, Telecom and Technology sectors react significantly to the contemporaneous monetary policy shocks, the Utilities and Oil \& Gas sectors do not respond to the monetary policy shocks. This could be attributed to the counter-cyclical nature of utility and oil \& gas sectors. The results are qualitatively similar to that of Bredin et al., (2007) for the UK equity market.

Next we investigate the response of 25 Fama-French style value-weighted portfolios formed on the basis of size and book-to-market ratio. The ERPs of Fama-French portfolios also react negatively to the structural monetary policy shocks. The ERPs of small cap stocks are more sensitive to the monetary policy shocks than the big cap stocks. The average sensitivity of the ERP of small stocks is -0.76 while the average sensitivity of ERP of big stocks is -0.55 . We can see that the average responsiveness of the ERP to the monetary policy shocks decreases as one move from small size portfolios to large size portfolios. The results confirm that small companies are more vulnerable to monetary policy shocks and therefore need to offer higher excess returns. Small firms relay heavily on bank as compared to big firms. Further, small firms are more "financially constrained" in the sense that they may be required to post additional good quality collateral for accessing bank credit facilities or to refinance the existing debt.

With regard to value and growth dimensions, the ERP of value stocks and growth stocks are expected to react differently. As shown by Kuttner, (2001), the short-end of the term structure reacts much more than the long-end of the term structure to the monetary policy shocks. Therefore, ERPs of companies whose revenues and earnings are sensitive to shortterm interest rate fluctuations will respond much more to the monetary policy shocks. Based on this reasoning and the way growth and value portfolios are constructed, it is reasonable to expect that the ERP of value stocks should be more sensitive to monetary policy shocks than the ERPs of growth stocks. Another reason for this difference is that value stocks have higher expected cash flows relative to their market prices as compared to the growth stocks. Therefore, any significant changes to the cash flows due to monetary policy shocks will have a more significant impact on the ERPs of value stocks than the ERPs of growth stocks.

Results reported in table 3 (see Appendix) clearly support the above reasoning. The ERP of value stocks are not only statistically sensitive to monetary policy shocks but also in terms of magnitude; the value stocks seems to be more sensitive to monetary policy shocks than that of growth stocks. The average sensitivity of the ERP of value stocks is -0.93 while the average sensitivity of ERP of growth stocks is -0.42. In summary, the ERPs of small size and value portfolios are more sensitive to the monetary policy shocks than the portfolios of big size and growth stocks.

\subsection{The impact of structural monetary policy shocks on ERP, before and after quantitative easing}

Next we examine the response of ERP to monetary policy shocks before and after the implementation of the QE. As discussed earlier, empirical evidence on the impact of unconventional monetary policy before and after QE on the UK's ERP is non-existent. For this purpose, we divide the sample into two groups using March 2009 as the breakpoint when the BOE launched the first round of QE. The pre-QE sample runs from January 1988 to February 2009 and the post-QE sample spans from March 2009 till October 2014.

\footnotetext{
${ }^{1}$ It is worth noting that though the BOE halted its QE programme in July 2012, the Bank is still maintaining its accommodative monetary policy stance.
} 
Table 4 (see Appendix) shows that the response of ERPs of aggregate FTSE indices and various sectoral indices, before and after the QE. By comparing columns (B) and (D) of table 4, we can see a remarkable difference between the sensitivity of ERPs. Before QE, ERPs react negatively to the structural monetary policy shocks as all beta coefficients are negative. While after the QE, sensitivities of the ERPs to the monetary policy shocks are positive for almost all industries, except for the Healthcare which shows a negative response. However, it is not statistically significant.

The magnitudes of the sensitivity of the ERPs to the monetary policy shocks in the post-QE period are higher. The ERPs of the various FTSE indices after the $\mathrm{QE}$ show greater response compared to the response before the QE. For example, before the QE, the sensitivity of ERP ofthe FTSE 100 index was $0.712 \%$ which suggests that a positive one percent change in the interest rate shock would decrease the ERP of the FTSE 100 index by an average of $0.712 \%$ (monthly). After the QE this sensitivity has increased to $2.4 \%$. The paired sample t-statistics with unequal variances (not reported) for the hypothesis that the average $\beta_{i, \text { before } Q E}=\beta_{i, \text { after } Q E}$ is -8.10 suggesting that the average response of the ERP of these FTSE indices to the monetary policy shocks before and after QE is statistically significantly different at $1 \%$ level.

Table 5 (see Appendix) reports the impact of monetary policy shocks on the ERPs of the 25 FamaFrench style value-weighted portfolios. We can see a similar pattern of reaction of ERPs of these portfolios before and after QE. Before QE, the ERPs respond negatively. However after QE, the ERPs are positive. The paired sample t-statistics with unequal variances for the hypothesis that the average $\beta_{\text {before } Q E}^{i}=\beta_{\text {after } Q E}^{i}$ is -14.23 suggesting that the average response of the ERP of these 25 portfolios to the monetary policy shocks before and after QE is statistically significantly different at $1 \%$ level. The average responses of the ERPs of small size portfolios (2.05) and value portfolios (3.39) to monetary policy shocks are still more than the ERPs of the big size (1.98) and growth portfolios (1.45) after QE.

One possible explanation for the asymmetric response is that increased liquidity may have inflated the prices of risky assets such as equities. Consequently any withdrawal of the liquidity from the markets induced by unexpected interest rate changes could potentially impact the prices of the risky assets and by extension the risk premium provided by these assets, i.e., the ERP. Another possible explanation is that during $\mathrm{QE}$, the $\mathrm{BoE}$ purchased high quality fixed income securities financed by central bank reserves thus effectively replacing relatively illiquid money with liquid cash reserves. This led to decline in both short and long term bond yields and, thus, leading to higher excess equity returns.

With an aim to examine the direct impact of monetary policy shocks when QE announcements were made, we run the following regression using maximum-likelihood estimation with heteroscedasticity consistent robust standard errors and covariance (Bollerslev and Woolridge, 1992) for the entire sample;

$$
E_{i, t}=\mu_{i}+\beta_{i} u_{t}^{m p}+\gamma_{i}\left(D \cdot u_{t}^{m p}\right)+e_{i, t},
$$

where, $E_{i, t}$ is the ERPs of the various FTSE indices and that of the 25 Fama-French portfolios, $u_{t}^{m p}$ is the monetary policy shocks (interest rate shocks) extracted from the SVAR (1), D is a binary dummy variable that takes a value 1 for the months when the MPC announced an increase in the QE and 0 otherwise. There were seven occasions when the MPC announced an increase in the QE. The parameter $\gamma_{i}$ captures the impact of interaction between monetary policy shocks and the month in which the changes to the QE were announced on ERP of the $i^{\text {th }}$ portfolio. The parameter $\beta_{i}$ is the sensitivity of ERP of the $i^{\text {th }}$ portfolio to monetary policy shocks.

By comparing columns (B) and (C) in Table 6 (see Appendix), we can clearly see the asymmetric impact of monetary policy shocks during the QE announcements as the $\gamma_{i}$ 's are positive and significant except for Utilities and Telecom sectors. Column (D) shows the Wald's F-statistic for the null hypothesis $\beta_{i}=\gamma_{i}=0$. Except for Consumer Goods and Utilities, the Wald statistic is statistically significant for the rest thus confirming the asymmetric response of ERPs to the monetary policy shocks. ${ }^{1}$ These results support the previous results reported in Table 4.

Panel C of Table 7 (see Appendix) show the impact of monetary policy shocks on the ERPs of the 25 Fama-French portfolios for the months when there was an announcement of $\mathrm{QE}$ programmes i.e. the parameter $\gamma_{i}$ in model (10). The results show statistically significant response to the QE programmes $\left(\gamma_{i}>0\right)$. Panel D presents the Wald's F-statistic for the null hypothesis that $\beta_{i}$ and $\gamma_{i}$ are jointly equal to zero. The null hypothesis is rejected for almost all the portfolios suggesting that the response of ERP of these 25 portfolios is asymmetric. These results support the earlier findings reported in Table 5.

\footnotetext{
${ }^{1}$ However, our results should be interpreted with caution since there may be other unobserved factors such as investor sentiments [see Brown and Cliff, 2005; Kumar and Lee, 2006 and Baker and Wurgler, 2006, 2007] which could influence the response of equity markets to the monetary policy shocks. That being said, those other factors could also be influenced by unexpected tightening/easing of monetary policy (Kurov, 2010).
} 


\section{Summary and conclusions}

The paper empirically investigates the impact of UK domestic monetary policy shocks on the ERPs of aggregate market, ten industries, as well as the 25 Fama-French style portfolios. We extract structural monetary policy shocks as residuals of the feedback rule from SVAR and study the asset pricing implications before and after the implementation of QE. The paper contributes to the existing literature by offering evidence of asymmetric response of ERP to monetary policy shocks before and after the implementation of unconventional monetary policy.

We find that for the entire sample period, the structural domestic monetary policy shocks have a statistically significant negative impact. Results suggest that a positive structural monetary policy shock i.e. when the actual interest rates are more than the expected interest rates, induces negative impact on the ERP of almost all of the sectoral indices. However the magnitude of the response to the monetary policy shocks is heterogeneous confirming the procyclical and counter cyclical behaviour of different industries. Empirical evidence for the ERPs of 25 Fama-French portfolios constructed on size and book to market characteristics also show similar heterogeneous impact. Overall the ERPs of small size stocks are more sensitive to the structural monetary policy shocks than the ERP of big size shocks suggesting the presence of the balance sheet and the bank lending channels of the monetary transmission. Similarly, ERPs of value portfolios are more sensitive to the monetary policy shocks than portfolios of growth stocks.

Last but not the least, we investigate the impact of monetary policy shocks on the ERPs of FTSE indices before and after QE. Our empirical results show that before the implementation of $\mathrm{QE}$, the monetary policy shocks have negative impact on the ERPs of aggregate market, various industries as well as Fama-French portfolios. However for the post-QE period, the impact is positive. The empirical evidence provided in the paper sheds light on the equity market's asymmetric response to the BoE's policy before and after the monetary stimulus.

\section{References}

1. Amisano G. and Giannini C. (1997). Topics in Structural VAR Econometrics. $2^{\text {nd }}$ ed. : Springer : Heidelberg and New York.

2. Baker, M. and Wurgler J. (2006). Investor Sentiment and the Cross-Section of Stock Returns, The Journal of Finance 61, pp. 1645-1680.

3. Baker, M. and Wurgler J. (2007). Investor Sentiment in the Stock Market, Journal of Economic Perspectives 21, pp. 129-151.

4. Ball, L.M., (1999). Policy Rules for Open Economies. In John, B. Taylor (ed.): Monetary Policy Rules University of Chicago Press, Chicago.

5. Ball, L.M., (1999). Efficient Rules for Monetary Policy, International Finance 2, pp. 66-83.

6. Bernanke, B.S. and Kuttner K.N. (2005). What Explains the Stock Market's Reaction to Federal Reserve Policy?, The Journal of Finance 60, pp. 1221-1257.

7. Bernanke, B.S. (1986). Alternative Explanations of the Money-Income Correlation, Carnegie-Rochester Conference Series on Public Policy Elsevier.

8. Bernanke, B.S. and Blinder A.S. (1992). The Federal Funds Rate and the Channels of Monetary Transmission, American economic review82, pp. 901-921.

9. Bjørnland,H.C. and Leitemo K. (2009). Identifying the Interdependence between US Monetary Policy and the Stock Market, Journal of Monetary Economics 56, pp. 275-282.

10. Bollerslev, T. and Woolridge, J. (1992). Quasi-maximum Likelihood Estimation and Inference in Dynamic Models with Time-varying Covariances, Econometric Reviews 11, pp. 143-172.

11. Bredin, D., Hyde, S., Nitzsche, D. and O'reilly, G. (2007). UK Stock Returns and the Impact of Domestic Monetary Policy Shocks, Journal of Business Finance \& Accounting 34, pp. 872-888.

12. Brown, G. W. and Cliff, M.T., (2005). Investor Sentiment and Asset Valuation, The Journal of Business 78, pp. 405-440.

13. Castelnuovo, E. and Nisticò, S. (2010). Stock Market Conditions and Monetary Policy in a DSGE model for the U.S., Journal of Economic Dynamics and Control 34, pp. 1700-1731.

14. Christiano, L. J., Eichenbaum, M. and Evans, C. (1996). The Effects of Monetary Policy Shocks: Evidence from the Flow of Funds, The Review of Economics and Statistics, pp. 78, 16-34.

15. Christiano, L. J., Eichenbaum, M. and Evans, C. (1999). Monetary Policy Shocks: What have We Learned and to What End?, in John.B. Taylor and in Michael Woodford ed.: Handbook of Macroeconomics. 1, Elsevier B.V.

16. Doh, B.T., Cao, G, and Molling, D. (2015). Should Monetary Policy Monitor Risk Premiums in Financial Markets?, Federal Reserve Bank of Kansas City: Economic Review 100, pp. 7-30.

17. Eggertsson, G. B. and Woodford, M. (2003). The Zero Bound on Interest Rates and Optimal Monetary Policy, Brookings Papers on Economic Activity 34, pp. 139-235.

18. Ehrmann, M. and Fratzscher, M. (2004). Taking Stock: Monetary Policy Transmission to Equity Markets, Journal of Money, Credit, and Banking 36, pp. 719-737. 
19. Friedman, M. (1961). The Lag in Effect of Monetary Policy, Journal of Political Economy 69, pp. 447-466.

20. Gagnon, J. ,Raskin, M., Remache, J., and Sack, B. (2010), Large-scale Asset Purchases by the Federal Reserve: Did They Work?, Federal Reserve Bank of New York Economic Policy Review 17, pp.41-59.

21. Gagnon, J. ,Raskin, M., Remache, J., and Sack, B. (2011). The Financial Market Effects of the Federal Reserve's Large-Scale Asset Purchases, International Journal of Central Banking 7, pp. 3-43.

22. Gali, J. (1992). How Well does the IS-LM Model Fit Postwar U.S. Data, The Quarterly Journal of Economics, 107, pp. 709-738.

23. Gilchrist, S. and Leahy, J.V., (2002), Monetary policy and Asset Prices, Journal of Monetary Economics 49,pp. 75-97.

24. Glick, R and Leduc, S. (2012), Central Bank Announcements of Asset Purchases and the Impact on Global Financial and Commodity Markets, Journal of International Money and Finance,31, pp. 2078-2101.

25. Gregory, A., Tharyan, R. and Christidis, A. (2013). Constructing and Testing Alternative Versions of Fama-French and Carhart Models in the UK, Journal of Business Finance and Accounting,40, pp. 172-214.

26. Ioannidis, C. and Kontonikas, A. (2008). The Impact of Monetary Policy on Stock Prices, Journal of Policy Modeling,30, pp. 33-53.

27. Joyce, M. A., Lasaosa, A., Stevens, I. and Tong, M, (2011), The Financial Market Impact of UK Quantitative Easing The Financial Market Impact of UK Quantitative Easing, International Journal of Central Banking 7, pp. 113-161.

28. Kilian, L. (2012). Structural Vector Autoregressions, in Nigar Hashimzade and in Michael Thornton ed.: Handbook of Research Methods and Applications in Empirical Macroeconomics: Edward Elgar: Cheltenham.

29. Kim, S. (2001). Effects of Monetary Policy Shocks on the Trade Balance in Small Open European Countries, Economics Letters, 71, pp. 197-203.

30. Krishnamurthy, A. and Vissing-Jorgensen, A. (2011), The Effects of Quantitative Easing on Interest Rates: Channels and Implications for Policy, Brookings Papers on Economic Activity, pp. 215-287.

31. Kumar, A., and Lee, C.M.C, 2006, Retail Investor Sentiment and Return Comovements, The Journal of Finance,61, pp. 2451-2486.

32. Kurov, A. (2010). Investor Sentiment and the Stock Market's Reaction to Monetary Policy, Journal of Banking \& Finance, 34, pp. 139-149.

33. Kuttner, K. N. (2001). Monetary Policy Surprises and Interest Rates: Evidence from the Fed Funds Futures Market, Journal of Monetary Economics,47, pp. 523-544.

34. Lastrapes, W.D. (1998). International Evidence on Equity Prices, Interest Rates and Money, Journal of International Money and Finance, 17, pp. 377-406.

35. Lutkephol, H. (2005). New Introduction to Multiple Time Series Analysis. ed: $2^{\text {nd }}$ Springer: New York.

36. Miles, D. (2011) Monetary Policy and Financial Dislocation, Royal Economic Society, London.

37. Miles, D. (2012). Asset Prices, Saving and the Wider Effects of Monetary Policy, Manchester Business Conference: Manchester.

38. Mishkin, F. (1996). The Channels of Monetry Transmission: Lessons for Monetary Policy.

39. Neri, S. (2004), Monetary Policy and Stock Prices: Theory and Evidence. Economic Working Papers.

40. Okun, A. M. (1962), Potential GNP - Its Measurment and Significance, American Statistical Association, Proceedings of Business and Economics Statistics. pp. 98-104.

41. Pagan, A. (1995). Three Econometric Methodologies: An Update, in L Oxley, George D.A.R, Roberts C.J, and S. Sayer (eds). Surveys in Econometrics Blackwell Publishing Inc: Oxford.

42. Rigobon, R., and Sack, B. (2003), Measuring The Reaction of Monetary Policy to the Stock Market, The Quarterly Journal of Economics, 118, pp. 639-669.

43. Rigobon, R., and Sack, B. (2004), The Impact of Monetary Policy on Asset Prices, Journal of Monetary Economics, 51, pp. 1553-1575.

44. Rozeff M. S., 1974, Money and Stock Prices, Journal of Financial Economics, 1, pp. 245-302.

45. Sims, C. A. (1992), Interpreting the Macroeconomic Time Series Facts: The Effects of Monetary Policy, European Economic Review,36, pp. 1001-1011.

46. Svensson, L.E. (2000). Open-economy Inflation Targeting, Journal of International Economics, 52, pp. $155-183$.

47. Taylor, J.B. (1993). Discretion Versus Policy Rules in Practice, Carnegie-Rochester Conference Series on Public Policy, 39, pp. 195-214.

48. Thorbecke, W. (1997). On Stock Market Returns and Monetary Policy, The Journal of Finance 52, pp. 635-655.

49. Tobin, J. (1969). A General Equilibrium Approach To Monetary Theory, Journal of Money, Credit and Banking,1, pp. $15-29$. 


\section{Appendix}

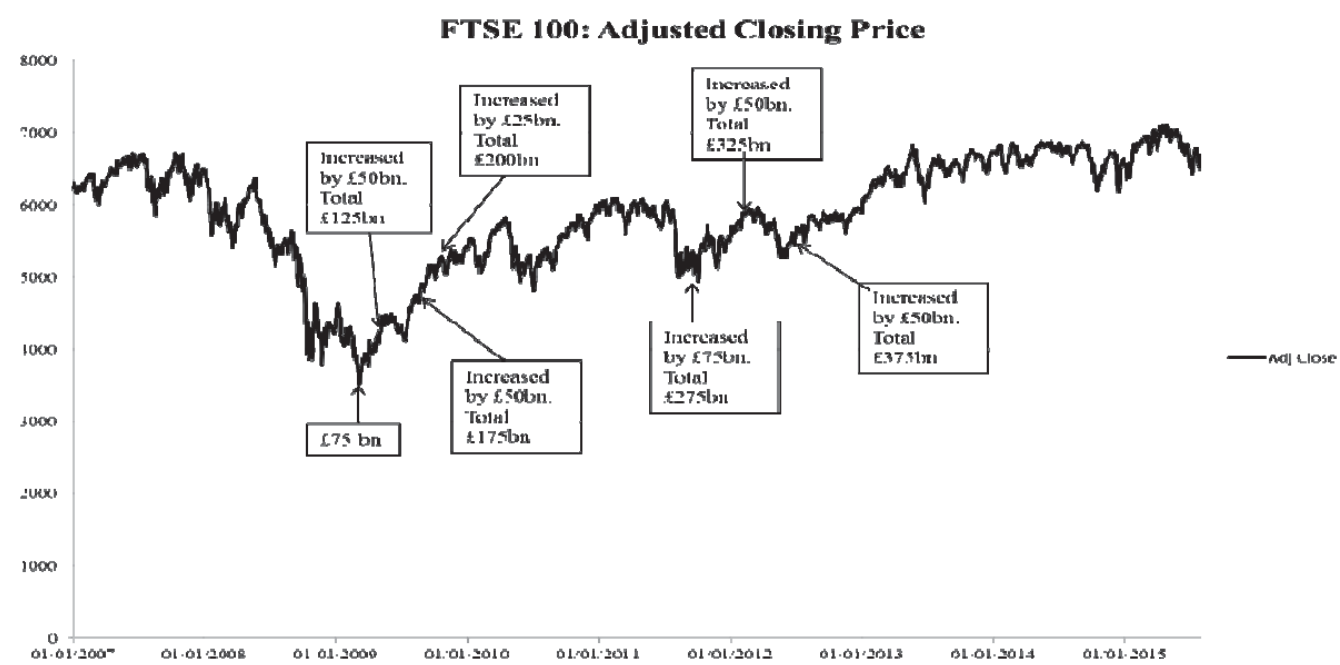

Fig. 1: FTSE 100 adjusted closing prices and the QE decisions

Table 1. Descriptive Statistics

\begin{tabular}{|l|c|c|c|c|c|}
\hline \multicolumn{2}{|c|}{ Descriptive } & $\Delta y$ & $\pi$ & Uemp & \multicolumn{2}{c|}{ Panel A } & \\
\hline & & & & \\
\hline Mean (\%) & 0.084 & 3.13 & 5.01 & -0.40 \\
\hline Median (\%) & 1.10 & 3.37 & 4.50 & -0.16 \\
\hline Standard Deviation (\%) & 3.20 & 1.41 & 2.178 & 5.5 & 5.37 \\
\hline Kurtosis & 2.98 & 8.69 & -0.58 & 4.55 \\
\hline Skewness & -0.73 & 1.15 & 0.77 & -1.01 \\
\hline No. of Months & 322 & 322 & 322 & 3.82 \\
\hline
\end{tabular}

Note: E100 is the excess return of FTSE 100 index. Similarly, E250 is for FTSE 250 index, EOnG is of FTSE All share Oil and Gas, EBM is of FTSE All share Basic Materials, Eind is of FTSE All share Industrials, ECGDs is of FTSE All share Consumer Goods, Ehlth is of FTSE All share Healthcare, ECSvs is of FTSE All share Consumer services, Etel is of FTSE All share Telecoms, Eutl is of FTSE All share utilities, Efin is of FTSE All share Financials and Etech is of FTSE All Share technology.

\begin{tabular}{|l|c|c|c|c|c|c|c|c|c|c|c|c|}
\hline \multicolumn{10}{|c|}{ Panel B } \\
\hline Descriptive & E100 & E250 & EOnG & EBM & Eind & ECGDs & Ehlth & ECSvs & Etel & Eutl & Efin & Etech \\
\hline Mean (\%) & 3.56 & 5.76 & 5.02 & 2.61 & 3.31 & 4.48 & 5.38 & 1.98 & 3.75 & 8.96 & 3.63 & 1.16 \\
\hline Median (\%) & 7.37 & 10.77 & 9.77 & 8.47 & 8.58 & 7.75 & 5.56 & 6.21 & 10.77 & 11.75 & 8.39 & 9.82 \\
\hline $\begin{array}{l}\text { Standard } \\
\text { Deviation (\%) }\end{array}$ & 14.46 & 17.17 & 18.93 & 23.97 & 19.98 & 19.97 & 14.17 & 16.64 & 19.52 & 15.51 & 19.99 & 29.86 \\
\hline Kurtosis & 0.64 & 2.5 & 0.825 & 4.30 & 2.24 & 0.81 & 0.53 & 1.36 & 0.85 & 0.37 & 2.42 & 3.28 \\
\hline Skewness & -0.47 & -0.77 & -0.30 & -0.91 & -0.84 & -0.34 & -0.035 & -0.58 & -0.49 & -0.12 & -0.55 & -0.62 \\
\hline No. of Months & 322 & 322 & 322 & 322 & 322 & 322 & 322 & 322 & 322 & 322 & 322 & 322 \\
\hline
\end{tabular}

Note: $\Delta y$ is the growth rate of index of industrial production, $\pi$ is inflation, Uemp is unemployment, $\Delta x$, growth rate of sterling effective exchange rate and $\mathrm{R}$ is the base rate.

Table 1. Continued

\begin{tabular}{|l|c|c|c|c|c|c|}
\hline \multicolumn{9}{|c|}{ Panel C } \\
\hline Portfolio & Mean (\%) & Median (\%) & Standard Deviation (\%) & Kurtosis & Skewness & No. of months \\
\hline SL & 4.01 & 8.61 & 21.91 & 2.25 & -0.22 & 322 \\
\hline S2 & 6.50 & 10.06 & 18.80 & 0.72 & -0.08 & 322 \\
\hline S3 & 6.96 & 11.72 & 17.82 & 2.25 & -0.02 & 322 \\
\hline S4 & 7.96 & 8.74 & 17.90 & 2.76 & -0.22 & 322 \\
\hline SH & 8.69 & 10.29 & 17.66 & 4.25 & 0.09 & 322 \\
\hline S2L & 3.08 & 7.53 & 23.10 & 2.66 & -0.16 & 322 \\
\hline S22 & 5.29 & 9.33 & 21.00 & 2.03 & -0.72 & 322 \\
\hline S23 & 6.37 & 8.46 & 18.61 & 1.55 & -0.24 & 322 \\
\hline
\end{tabular}


Table 1. Continued

\begin{tabular}{|l|c|c|c|c|c|c|}
\hline S24 & 7.07 & 6.12 & 19.32 & 1.30 & -0.06 & 322 \\
\hline S2H & 7.50 & 12.97 & 22.26 & 5.95 & 0.33 & 322 \\
\hline M3L & 4.41 & 12.99 & 22.89 & 5.92 & -0.81 & 322 \\
\hline M32 & 3.56 & 9.17 & 20.58 & 1.79 & -0.25 & 322 \\
\hline M33 & 6.29 & 11.58 & 19.67 & 3.62 & -0.84 & 322 \\
\hline M34 & 5.69 & 8.90 & 20.71 & 1.64 & -0.17 & 322 \\
\hline M3H & 9.87 & 9.22 & 21.93 & 3.37 & 0.05 & 322 \\
\hline B4L & 7.91 & 15.17 & 20.55 & 4.35 & 0.07 & 322 \\
\hline B42 & 4.82 & 2.37 & 18.92 & 3.42 & -0.31 & 322 \\
\hline B43 & 8.76 & 7.57 & 18.49 & 1.66 & -0.39 & 322 \\
\hline B44 & 6.77 & 15.19 & 21.43 & 2.08 & -0.25 & 322 \\
\hline B4H & 7.58 & 10.52 & 22.17 & 3.17 & -0.26 & 322 \\
\hline BL & 4.51 & 5.79 & 14.45 & 0.30 & -0.14 & 322 \\
\hline B2 & 4.32 & 7.71 & 15.11 & 0.71 & -0.40 & 322 \\
\hline B3 & 5.58 & 6.51 & 17.10 & 1.46 & -0.32 & 322 \\
\hline B4 & 5.98 & 10.48 & 17.30 & 1.54 & -0.37 & 322 \\
\hline BH & 5.39 & 9.91 & 18.80 & 1.53 & -0.26 & 322 \\
\hline
\end{tabular}

Note : This panel provides annualised descriptive statistics of the ERPs of the 25 value-weighted Fama-French style portfolios constructed on the basis of size and book-to-market characteristics. The naming convention is same as in Gregory, Tharyan and Christidis, (2013). For example, "SH" denotes small cap-high book-to-market (BTM), "S4" denotes small and 4th lowest BTM, "B4" denotes big and 4th highest BTM, "BH" denotes big size and highest BTM, "M3L" middle $3^{\text {rd }}$ size and largest BTM and "M32" middle $3^{\text {rd }}$ size and $2^{\text {nd }}$ BTM

Table 2. The impact of monetary policy shocks on ERP using base rate as monetary policy instrument

\begin{tabular}{|c|c|c|c|}
\hline FTSE Indices & $\alpha_{i}$ & $\beta_{i}$ & S.E of Regression \\
\hline \multirow[t]{2}{*}{ FTSE 100} & $0.56^{* *}$ & $-0.609^{* *}$ & 0.042 \\
\hline & $(2.60)$ & $(-2.36)$ & \\
\hline \multirow[t]{2}{*}{ FTSE 250} & $0.78^{* * *+}$ & $-0.521^{*}$ & 0.049 \\
\hline & $(2.89)$ & $(-2.07)$ & \\
\hline \multirow[t]{2}{*}{ Basic materials } & 0.459 & $-0.756^{* \prime}$ & 0.069 \\
\hline & $(1.23)$ & $(-2.45)$ & \\
\hline \multirow[t]{2}{*}{ Consumer services } & $0.591^{* *}$ & $-0.648^{* * *}$ & 0.048 \\
\hline & $(2.28)$ & $(-2.58)$ & \\
\hline \multirow[t]{2}{*}{ Financials } & $0.65^{* *}$ & $-0.743^{* *}$ & 0.058 \\
\hline & $(2.05)$ & $(-2.16)$ & \\
\hline \multirow[t]{2}{*}{ Consumer goods } & $0.625^{* *}$ & $-0.474^{*}$ & 0.058 \\
\hline & (2.10) & $(-1.67)$ & \\
\hline \multirow[t]{2}{*}{ Healthcare } & $0.626^{*+2}$ & $-0.468^{*}$ & 0.040 \\
\hline & $(2.89)$ & $(-1.86)$ & \\
\hline \multirow[t]{2}{*}{ Industrials } & $0.55^{*}$ & $-0.615^{* *}$ & 0.057 \\
\hline & $(1.90)$ & (2.15) & \\
\hline \multirow[t]{2}{*}{ Oil and gas } & $0.501^{*}$ & -0.439 & 0.054 \\
\hline & (1.74) & $(-1.13)$ & \\
\hline \multirow[t]{2}{*}{ Utilities } & $0.895^{*+*}$ & 0.181 & 0.044 \\
\hline & $(3.66)$ & $(0.69)$ & \\
\hline \multirow[t]{2}{*}{ Telecom } & $0.596^{* *}$ & $-0.709^{* *}$ & 0.056 \\
\hline & (2.13) & $(-2.28)$ & \\
\hline \multirow[t]{2}{*}{ Technology } & 0.475 & $-0.948^{* * *+}$ & 0.087 \\
\hline & (1.4) & $(-2.46)$ & \\
\hline
\end{tabular}

Note: The model estimated is (9). The dependent variable is the ERP of the FTSE indices (in percent). The independent variable is the structural base rate shock in the UK. Adjusted sample size Feb 1989 - Oct 2014 (no. of observations 309). The coefficients denote monthly sensitivities of the ERP of the FTSE indices to monetary policy shocks (in decimals) $* * *$ significant at $1 \%$, ** significant at $5 \%$ and $*$ significant at $10 \%$. Figures in the parentheses are z-statistics. 
Table 3. The impact of monetary policy shocks on the ERP of the 25 value-weighted Fama-French portfolios

\begin{tabular}{|c|c|c|c|c|c|c|c|c|c|c|c|}
\hline \multicolumn{6}{|c|}{$\alpha_{i}$} & & \multicolumn{5}{|l|}{ Z-stat } \\
\hline & Small & Size 2 & Size 3 & Size 4 & Large & Average & & & & & \\
\hline Growth & $0.701^{*}$ & $0.50^{*}$ & $0.76^{* *}$ & $0.92^{*+*}$ & $0.76^{* * *}$ & 0.73 & (1.91) & $(1.66)$ & $(2.22)$ & $(2.78)$ & $(3.47)$ \\
\hline BM2 & $0.882^{\text {tw+ }}$ & $0.74^{* \prime}$ & $0.82^{* *}$ & $0.78^{* *}$ & $0.71^{t+*}$ & 0.78 & $(3.08)$ & $(2.18)$ & $(2.49)$ & (2.27) & (2.91) \\
\hline BM3 & $0.95^{\text {t*t }}$ & $0.73^{\prime \prime}$ & $0.83^{t+*+}$ & $0.85^{* * *}$ & $0.72^{+* *+}$ & 0.82 & (3.37) & (2.22) & (2.93) & $(3.08)$ & $(3.03)$ \\
\hline BM4 & $0.97^{* * *}$ & $0.88^{* * *}$ & $0.54^{*}$ & $0.67^{* \prime}$ & $0.58^{* * *}$ & 0.73 & (3.75) & $(2.6)$ & (1.94) & $(2.39)$ & (2.72) \\
\hline Value & $0.96^{*+*}$ & $0.92^{* * *}$ & $0.76^{* *}$ & $0.97^{* * *}$ & $0.67^{\prime \prime}$ & 0.86 & (3.74) & (3.0) & (2.22) & $(3.09)$ & $(2.52)$ \\
\hline Average & 0.89 & 0.75 & 0.81 & 0.84 & 0.69 & & & & & & \\
\hline \multicolumn{7}{|c|}{$\beta_{i}$} & \multicolumn{5}{|c|}{ Z-Stat } \\
\hline & Small & Size 2 & Size 3 & Size 4 & Large & Average & & & & & \\
\hline Growth & $-0.64^{*+*+}$ & $-0.76^{\text {t*t }}$ & -0.2 & -0.23 & -0.26 & -0.42 & $(-2.66)$ & $(-2.70)$ & $(-0.81)$ & $(-0.72)$ & $(-0.97)$ \\
\hline BM2 & $-0.48^{*+}$ & $-0.49^{*}$ & $-0.95^{*+*}$ & $-0.64^{* *}$ & $-0.92^{+*+1}$ & -0.69 & $(-2.02)$ & $(-1.81)$ & $(-3.33)$ & $(-2.17)$ & $(-3.13)$ \\
\hline BM3 & $-0.77^{*+1+}$ & $-0.62^{*+}$ & $-0.59^{* *}$ & $-0.78^{* * *+}$ & $-0.59^{* *}$ & -0.67 & $(-3.39)$ & $(-2.20)$ & $(-2.14)$ & $(-2.63)$ & $(-2.34)$ \\
\hline BM4 & $-0.99^{\text {t*t }}$ & $-1.04^{*+*+}$ & -0.34 & -0.73 & -0.43 & -0.71 & $(-4.92)$ & $(-3.98)$ & $(-1.25)$ & $(-2.59)$ & $(-1.53)$ \\
\hline Value & $-0.92^{*+*}$ & $-0.85^{* * *+}$ & $-1.24^{* *+*}$ & $-1.07^{* *+}$ & $-0.56^{*+}$ & -0.93 & $(-4.85)$ & $(-2.59)$ & $(-4.31)$ & $(-3.56)$ & $(-2.24)$ \\
\hline Average & -0.76 & -0.752 & -0.664 & -0.69 & -0.552 & & & & & & \\
\hline
\end{tabular}

Table 4. The impact of structural monetary shocks on ERP: Pre and post quantitative easing

\begin{tabular}{|c|c|c|c|c|}
\hline \multirow[b]{2}{*}{ ERP of FTSE Indices } & \multicolumn{2}{|c|}{ 1989:02 - 2009:02-Pre-QE (241 observations) } & \multicolumn{2}{|c|}{ 2009:03 - 2014:10: Post QE (68 observations) } \\
\hline & (A) $\alpha_{i}$ & (B) $\beta_{i}$ & (C) $\alpha_{i}$ & (D) $\beta_{i}$ \\
\hline \multirow[t]{2}{*}{ FTSE 100} & $0.566^{*+}$ & $-0.712^{+* * *}$ & $1.095^{*+*+1}$ & $2.367^{+*+*}$ \\
\hline & $(2.38)$ & $(-2.61)$ & (2.66) & (2.72) \\
\hline \multirow[t]{2}{*}{ FTSE 250} & $0.645^{*+}$ & $-0.605^{*+}$ & $1.864^{* *++}$ & $2.142^{*+*}$ \\
\hline & $(2.08)$ & $(-2.24)$ & $(3.91)$ & (21.8) \\
\hline \multirow[t]{2}{*}{ Basic Materials } & 0.521 & $-0.829^{+*+*}$ & 0.632 & $2.617^{+* n+1}$ \\
\hline & $(1.39)$ & $(-2.62)$ & $(0.63)$ & $(9.03)$ \\
\hline \multirow[t]{2}{*}{ Consumer Services } & 0.461 & $-0.751^{1+*}$ & $1.07^{+*+*}$ & $1.73^{*}$ \\
\hline & $(1.50)$ & $(-2.78)$ & $(2.65)$ & $(1.80)$ \\
\hline \multirow[t]{2}{*}{ Financials } & $0.634^{*}$ & $-0.858^{* *}$ & $1.21^{* *}$ & $3.16^{*+1}$ \\
\hline & $(1.75)$ & $(-2.31)$ & $(2.28)$ & $(2.50)$ \\
\hline \multirow[t]{2}{*}{ Consumer Goods } & -0.248 & $-0.639^{*}$ & $1.38^{*+*}$ & $1.78^{*+*}$ \\
\hline & $(-0.65)$ & $(-1.74)$ & $(4.60)$ & $(2.48)$ \\
\hline \multirow[t]{2}{*}{ Healthcare } & $0.453^{*}$ & $-0.536^{*+}$ & $1.19^{* *}$ & -0.113 \\
\hline & $(1.76)$ & $(-1.96)$ & $(3.00)$ & $(-0.89)$ \\
\hline \multirow[t]{2}{*}{ Industrials } & 0.321 & $-0.764^{* *}$ & $1.27^{+*+}$ & $2.14^{4+*}$ \\
\hline & $(0.94)$ & $(-2.37)$ & $(2.79)$ & $(5.17)$ \\
\hline \multirow[t]{2}{*}{ Oil and Gas } & $0.551^{*}$ & -0.552 & 0.498 & $1.97^{*+}$ \\
\hline & $(1.70)$ & $(-1.35)$ & $(1.01)$ & $(2.20)$ \\
\hline \multirow[t]{2}{*}{ Utilities } & $0.569^{* * *}$ & -0.324 & $1.15^{\text {t*t+ }}$ & 0.54 \\
\hline & $(30.64)$ & $(-1.01)$ & $(3.11)$ & $(0.64)$ \\
\hline \multirow[t]{2}{*}{ Telecom } & 0.399 & $-0.771^{* *}$ & $1.30^{+*+1}$ & 0.085 \\
\hline & $(1.52)$ & $(-2.29)$ & $(2.67)$ & $(0.09)$ \\
\hline \multirow[t]{2}{*}{ Technology } & -0.05 & $-1.10^{*+*}$ & $1.936^{*+*+}$ & $2.09^{\circ}$ \\
\hline & $(0.91)$ & $(-3.67)$ & (2.97) & $(1.85)$ \\
\hline
\end{tabular}

Note: The model estimated is (9). The dependent variable is the ERP of the FTSE indices (in percent). The independent variable is the domestic monetary policy shock in the UK. Two different samples are used. The pre-QE adjusted sample is from Feb-1989 to Feb-2009 and the post QE sample is March -2009 to till Oct-2010. The data is monthly. *** significant at 1\%, ** significant at 5\% and * significant at $10 \%$. The coefficients denote monthly sensitivities of the ERP of the FTSE indices to monetary policy shocks (in decimals). Figures in the parentheses are z-statistics.

Table 5. The impact of structural monetary policy shocks on the ERP of the 25 value-weighted Fama-French portfolios: pre and post quantitative easing

\begin{tabular}{|c|c|c|c|c|c|c|c|c|c|c|c|c|c|}
\hline \multicolumn{7}{|c|}{ Before QE } & \multicolumn{7}{|c|}{ After QE } \\
\hline \multicolumn{7}{|c|}{$\alpha_{i}$} & \multicolumn{7}{|c|}{$\alpha_{i}$} \\
\hline & Small & Size 2 & Size 3 & Size 4 & Large & Average & & Small & Size 2 & Size 3 & Size 4 & Large & Average \\
\hline Growth & 0.5 & 0.48 & 0.34 & $0.70^{*}$ & $0.62^{* *}$ & 0.528 & Growth & $1.09^{\prime \prime}$ & $1.45^{\prime \prime}$ & $1.99 *$ & $1.53^{* *}$ & 1.07 & 1.426 \\
\hline BM2 & $0.65^{*}$ & 0.41 & 0.49 & 0.54 & $0.69^{* *+*}$ & 0.556 & BM2 & $1.39^{\prime \prime \prime}$ & $2.19^{\prime \prime \prime}$ & $2.19^{\prime \prime \prime}$ & $1.45^{* \prime}$ & 0.63 & 1.57 \\
\hline
\end{tabular}


Table 5. (cont.). The impact of structural monetary policy shocks on the ERP of the 25 value-weighted Fama-French portfolios: pre and post quantitative easing

\begin{tabular}{|c|c|c|c|c|c|c|c|c|c|c|c|c|c|}
\hline BM3 & $0.66^{\prime \prime}$ & 0.28 & $0.57^{*}$ & $0.69^{* *}$ & $0.69^{* * *}$ & 0.578 & BM3 & $2.80^{* * *+}$ & $1.83^{* * *}$ & $1.58^{\prime \prime \prime}$ & $1.99^{\prime \prime \prime}$ & 1.27 & 1.894 \\
\hline BM4 & $0.83^{* * *}$ & 0.57 & -0.91 & 0.42 & 0.39 & 0.26 & BM4 & $2.04^{*+* t}$ & $1.82^{* * *}$ & $1.54^{\prime \prime \prime}$ & $1.93^{* *}$ & 1.2 & 1.706 \\
\hline Value & $0.75^{\ldots *}$ & $0.80^{* \prime}$ & $1.23^{* * *}$ & $0.87^{* *}$ & $0.67^{* *}$ & 0.864 & Value & $2.03^{\text {t.t+ }}$ & $2.02^{* * *}$ & $1.51^{* *}$ & $2.03^{\prime \prime \prime}$ & 0.89 & 1.696 \\
\hline Average & 0.678 & 0.508 & 0.344 & 0.644 & 0.612 & & Average & 1.87 & 1.862 & 1.762 & 1.786 & 1.012 & \\
\hline \multicolumn{7}{|c|}{$\beta_{i}$} & & \multicolumn{6}{|c|}{$\beta_{i}$} \\
\hline & Small & Size 2 & Size 3 & Size 4 & Large & Average & & Small & Size 2 & Size 3 & Size 4 & Large & Average \\
\hline Growth & $-0.66^{\prime \prime}$ & $-0.95^{* * *}$ & -0.25 & -0.38 & -0.39 & -0.526 & Growth & $-0.72^{* * *}$ & $2.20^{\circ}$ & 2.13 & $2.12^{\prime \prime}$ & $1.51^{*}$ & 1.45 \\
\hline BM2 & $-0.58^{\prime \prime}$ & $-0.54^{*}$ & $-1.05^{\prime \prime \prime}$ & $-0.73^{* *}$ & $-1.02^{* * *}$ & -0.784 & BM2 & 2.01 & $2.41^{\circ}$ & $1.54^{* * *}$ & $1.89^{\prime \prime \prime}$ & 1.66 & 1.902 \\
\hline BM3 & $-0.78^{* * *}$ & $-0.73^{* *}$ & $-0.72^{*+}$ & $-0.96^{\text {t** }}$ & $-0.70^{* * *+}$ & -0.778 & BM3 & $2.81^{* *}$ & 1.79 & $2.02^{*}$ & $2.29^{*}$ & $3.44^{*+*+}$ & 2.47 \\
\hline BM4 & $-1.01^{\prime \prime \prime}$ & $-1.07^{* * *}$ & -0.42 & $-0.85^{+* * *}$ & $-0.63^{* *}$ & -0.796 & BM4 & $2.64^{*+* t}$ & 1.64 & 3.37 & 3.04 & $1.63^{* *}$ & 2.464 \\
\hline Value & $-0.95^{* * *}$ & $-0.87^{* *}$ & $-1.25^{\prime \prime \prime}$ & $-1.13^{* * * *}$ & $-0.68^{* *+1}$ & -0.976 & Value & $3.51^{\text {t*t }}$ & $4.93^{* *}$ & $3.69^{* *}$ & $3.13^{*}$ & $1.69^{* *}$ & 3.39 \\
\hline Average & -0.796 & -0.832 & -0.738 & -0.81 & -0.684 & & Average & 2.05 & 2.594 & 2.55 & 2.494 & 1.986 & \\
\hline
\end{tabular}

Note: The model estimated is (9). The dependent variable is the ERP of the 25 Fama-French style portfolios. The independent variable is the structural domestic monetary policy shock in the UK. Two different samples are used. The Before-QE adjusted sample is from Feb-1989 to Feb-2009 and the After QE sample is March -2009 to till Oct-2010. The data is monthly. *** significant at $1 \%$, ** significant at $5 \%$ and $*$ significant at $10 \%$.

Table 6. The impact of monetary policy shocks on ERP using base rate as monetary policy instrument.

\begin{tabular}{|c|c|c|c|c|}
\hline ERP of FTSE Indices & $\mu_{i}$ & $\beta_{i}$ & $\gamma_{i}$ & $\begin{array}{c}\text { Wald's F-stat(Null: } \\
\left.\beta_{i}=\gamma_{i}=0\right)\end{array}$ \\
\hline & (A) & (B) & (C) & (D) \\
\hline \multirow[t]{2}{*}{ FTSE 100} & $0.51^{* *}$ & $-0.64^{+*+*}$ & $8.93^{*+*+}$ & $13.31^{\text {**** }}$ \\
\hline & (2.59) & $(-2.64)$ & $(4.68)$ & \\
\hline \multirow[t]{2}{*}{ FTSE 250} & 0.74 & -0.54 & $8.99^{*+*}$ & $12.52^{*+*}$ \\
\hline & $(3.20)$ & $(-1.56)$ & $(4.97)$ & \\
\hline \multirow[t]{2}{*}{ Basic materials } & 0.40 & $-0.78^{*}$ & $15.09^{* *}$ & $4.19^{* *}$ \\
\hline & $(1.31)$ & $(-1.69)$ & $(2.47)$ & \\
\hline \multirow[t]{2}{*}{ Consumer services } & $0.54^{* \prime \prime}$ & $-0.68^{*+}$ & $6.71^{+* *}$ & $7.98^{4+2}$ \\
\hline & (2.46) & $(-2.05)$ & $(3.72)$ & \\
\hline \multirow[t]{2}{*}{ Financials } & $0.60^{* *}$ & $-0.77^{\text {t* }}$ & $12.46^{*+*}$ & $16.40^{*+*}$ \\
\hline & $(2.46)$ & $(-2.36)$ & $(5.39)$ & \\
\hline \multirow[t]{2}{*}{ Consumer goods } & $0.59^{\prime \prime}$ & -0.50 & 3.20 & 1.84 \\
\hline & $(2.16)$ & $(-1.45)$ & $(1.40)$ & \\
\hline \multirow[t]{2}{*}{ Healthcare } & $0.59^{* *}$ & $-0.50^{*}$ & $4.53^{*+*}$ & $15.01^{+*+*}$ \\
\hline & $(2.85)$ & $(-1.92)$ & $(5.46)$ & \\
\hline \multirow[t]{2}{*}{ Industrials } & $0.50^{*}$ & $-0.65^{*}$ & $8.23^{* * *}$ & $5.02^{+*+*}$ \\
\hline & $(1.79)$ & $(-1.78)$ & $(2.76)$ & \\
\hline \multirow[t]{2}{*}{ Oil and gas } & 0.39 & $-0.51^{*}$ & $10.18^{* * *}$ & $14.37^{* * *}$ \\
\hline & $(1.38)$ & $(-1.89)$ & $(5.20)$ & \\
\hline \multirow[t]{2}{*}{ Utilities } & $0.90^{* * *}$ & 0.19 & -0.35 & 0.19 \\
\hline & $(4.44)$ & $(0.61)$ & $(-0.07)$ & \\
\hline \multirow[t]{2}{*}{ Telecom } & $0.57^{* *}$ & $-0.73^{*+*}$ & 3.00 & $3.03^{* *}$ \\
\hline & $(2.26)$ & $(-2.37)$ & $(0.99)$ & \\
\hline \multirow[t]{2}{*}{ Technology } & 0.39 & $-1.00^{\circ}$ & $9.65^{* * *}$ & $31.49^{*+*+1}$ \\
\hline & $(1.20)$ & $(-1.83)$ & $(7.83)$ & \\
\hline
\end{tabular}

Note: The model estimated is (10). The dependent variable is the ERP of the FTSE indices (in percent). The independent variables are the structural base rate shock and the interaction between them and the QE announcement months in the UK. Adjusted sample size Feb 1989 - Oct 2014 (no. of observations 309). *** significant at 1\%, ** significant at 5\% and * significant at 10\%. Figures in the parentheses are z-statistics.

Table 7. The Impact of monetary policy shocks on the ERP of the 25 value-weighted Fama-French portfolios

\begin{tabular}{|l|c|c|c|c|c|c|c|c|c|c|}
\hline \multicolumn{10}{|c|}{ Panel A } \\
\hline
\end{tabular}


Table 7. (cont.). The Impact of monetary policy shocks on the ERP of the 25 value-weighted Fama-French portfolios

\begin{tabular}{|c|c|c|c|c|c|c|c|c|c|c|c|}
\hline BM3 & $0.93^{* \star \star}$ & $0.69^{\star *}$ & $0.78^{* * *}$ & $0.81^{* \star *}$ & $0.68^{* * *}$ & 0.778 & (4.21) & $(2.35)$ & $(2.85)$ & $(2.83)$ & (2.61) \\
\hline BM4 & $0.96^{\star \star \star}$ & $0.84^{\star \star \star}$ & $0.51^{\star}$ & $0.65^{\star \star}$ & $0.53^{\star \star}$ & 0.698 & (4.32) & (3.12) & $(1.69)$ & (2.5) & (2.46) \\
\hline Value & $0.94^{\star \star \star}$ & $0.84^{\star \star *}$ & $1.15^{\star \star \star}$ & $0.93^{* * *}$ & $0.59^{\star \star}$ & 0.89 & $(4.3)$ & $(2.91)$ & $(4.19)$ & $(3.51)$ & $(2.3)$ \\
\hline Average & 0.88 & 0.652 & 0.782 & 0.796 & 0.638 & & & & & & \\
\hline \multicolumn{12}{|c|}{ Panel B } \\
\hline \multicolumn{7}{|c|}{$\beta_{i}$} & \multicolumn{5}{|c|}{ Z-stat } \\
\hline & Small & Size 2 & Size 3 & Size 4 & Large & Average & & & & & \\
\hline Growth & -0.65 & $-0.77^{\star *}$ & -0.21 & -0.26 & -0.3 & -0.438 & $(-1.18)$ & $(-1.99)$ & $(-0.48)$ & $(-0.67)$ & -1.15 \\
\hline BM2 & -0.48 & -0.03 & $-0.98^{\star \star}$ & -0.68 & $-0.94^{\star \star \star}$ & -0.622 & $(-1.14)$ & $(-0.08)$ & $(-2.23)$ & $(-1.47)$ & $(-3.53)$ \\
\hline BM3 & $-0.78^{\star}$ & -0.64 & -0.63 & $-0.81^{* \star}$ & $-0.61^{*}$ & -0.694 & $(-1.75)$ & $(-1.33)$ & $(-1.58)$ & $(-2.20)$ & $(-1.90)$ \\
\hline BM4 & $-1.00^{\star \star}$ & $-1.06^{\star *}$ & -0.37 & $-0.78^{* *}$ & $-0.49^{*}$ & -0.74 & $(-2.43)$ & $(-2.34)$ & $(-0.89)$ & $(-1.98)$ & $(-1.95)$ \\
\hline Value & $-0.92^{\star \star}$ & $-0.85^{\star \star}$ & $-1.25^{\star \star \star}$ & $-1.09^{\star \star \star}$ & -0.61 & -0.944 & $(-2.15)$ & $(-2.39)$ & $(-2.85)$ & $(-2.85)$ & $(-1.61)$ \\
\hline Average & -0.766 & -0.67 & -0.688 & -0.724 & -0.59 & & & & & & \\
\hline \multicolumn{12}{|c|}{ Panel C } \\
\hline \multicolumn{7}{|c|}{$Y_{i}$} & \multicolumn{5}{|c|}{ Z-stat } \\
\hline & Small & Size 2 & Size 3 & Size 4 & Large & Average & & & & & \\
\hline Growth & $4.28^{\star \star}$ & $6.29^{* \star *}$ & $4.87^{\star \star \star}$ & $7.52^{\star \star \star}$ & $3.96^{\star \star}$ & 5.74 & (2.3) & (3.1) & $(4.31)$ & $(5.65)$ & $(2.37)$ \\
\hline BM2 & -0.72 & $7.87^{\star \star \star}$ & $12.29^{\star \star \star \star}$ & $11.12^{\star \star \star}$ & $10.08^{\star * *}$ & 7.64 & $(-0.21)$ & $(3.38)$ & (3.91) & (3.03) & (6.02) \\
\hline BM3 & 6.36 & $4.70^{\star * *}$ & $8.06^{\star \star \star}$ & $7.07^{\star \star \star}$ & $9.24^{\star \star \star}$ & 6.548 & $(1.52)$ & $(2.58)$ & (2.76) & $(3.78)$ & (3.39) \\
\hline BM4 & $7.46^{\star}$ & $8.63^{*}$ & $9.75^{\star \star \star}$ & $14.29^{\star \star}$ & $7.84^{* \star *}$ & 10.03 & $(1.76)$ & $(1.8)$ & $(3.67)$ & (2.23) & (3.58) \\
\hline Value & 9.54 & $20.73^{\star *}$ & $13.99^{\star \star}$ & $13.72^{\star \star \star}$ & $8.60^{\star \star \star}$ & 14.5 & $(1.53)$ & (2.2) & $(1.98)$ & $(3.08)$ & (3.41) \\
\hline Average & 5.384 & 9.644 & 9.792 & 10.74 & 7.944 & & & & & & \\
\hline \multicolumn{12}{|c|}{ Panel D } \\
\hline \multicolumn{12}{|c|}{ Wald's Statistics $\left(\mathrm{H}_{0}: \beta_{\mathrm{i}}=\mathrm{V}_{\mathrm{i}}=0\right)$} \\
\hline & Small & Size 2 & Size 3 & Size 4 & Large & & & & & & \\
\hline Growth & $2.87^{\star}$ & $5.87^{* \star *}$ & $10.25^{\star * *}$ & $16.53^{\star * *}$ & $3.15^{\star *}$ & & & & & & \\
\hline BM2 & 0.71 & $5.79^{\star \star *}$ & $9.24^{\star \star \star}$ & $5.11^{* \star \star}$ & $21.03^{\star \star \star}$ & & & & & & \\
\hline BM3 & $2.46^{*}$ & $3.56^{\star \star}$ & $4.68^{\star \star \star}$ & $8.33^{\star \star \star}$ & $6.82^{* \star \star}$ & & & & & & \\
\hline BM4 & $4.18^{\star *}$ & $4.01^{* *}$ & $6.76^{* * *}$ & $4.69^{* * *}$ & $7.85^{\star * \star}$ & & & & & & \\
\hline Value & $3.33^{\star *}$ & $5.23^{\star \star *}$ & $5.87^{\star \star *}$ & $7.99^{\star \star \star}$ & $6.28^{\star \star \star}$ & & & & & & \\
\hline
\end{tabular}

Note: The model estimated is (10). The dependent variable is the ERP of the 25 Fama-French portfolios in percent. The independent variable is the domestic monetary policy shock in the UK. Adjusted sample size 1988:08 - 2014:10 (no. of observations 315) $* * *$ significant at $1 \%, * *$ significant at $5 \%$ and $*$ significant at $10 \%$.Figures in the parentheses are z-statistics. 